\title{
KARSTIC AQUIFER OF ORFANA-IPERIA OF WEST THESSALY. THE RESEARCH AND ANALYSIS OF THE HYDRODYNAMIC AND HYDROCHEMICAL STATUS BEFORE THE APPLICATION OF ARTIFICIAL GROUND WATER RECHARGE
}

\author{
Papagiannis N. ${ }^{1}$, Koumantakis $\mathbf{I}^{1}{ }^{1}$ and Vasileiou E. ${ }^{1}$ \\ ${ }^{1}$ National Technical University of Athens, School of Mining \& Metallurgical Engineering, \\ Laboratory of Engineering Geology \& Hydrogeology, Heroon Polytechniou 9, 15780, Athens, \\ Greece,nikospapag88@gmail.com,koumantakisioannis@gmail.com,elvas@metal.ntua.gr
}

\begin{abstract}
The aim of the work is to investigate and analyze the hydrodynamic and hydrochemical status of the karstic aquifer of Orfana-Iperia in West Thessaly before the application of its artificial recharge. The works of the artificial recharge, which is under construction, will be achieved by the divertion of a portion of the flow of Enipeas River. Regarding the geology and hydrogeology of Orfana-Iperia site, the geological and hydrogeological maps of the area, along with the depiction of the hydro-graphic network were constructed by means of GIS and are presented. Moreover, the hydrological analysis of the Enipeas river basin is included. The analysis was made using the hydraulic software "Hydrognomon". The piezometric analysis of the area is performed via piezometric maps produced using GIS and the "Surfer" software. The water table measurements of the aquifer system were provided by the Geology and Mineral Investigations Institute and by local organizations of reclamation. Furthermore, water sampling has been done in the area and after analysis, hydro-chemical diagrams were constructed by "Aquachem" software. Finally, the proposed method of the artificial recharge is described. The hydrogeological and hydrochemical analysis of the karstic aquifer before application of ground water recharge is very important for the future qualitative and quantitative comparison of groundwater today drawing conclusions.
\end{abstract}

Keywords: hydrogeology, hydrological analysis, hydro-chemical diagrams, "Hydrognomon", GIS.

\section{Пєрí $\eta \psi \eta$}

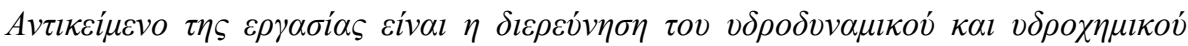

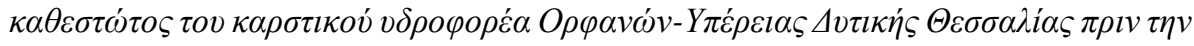

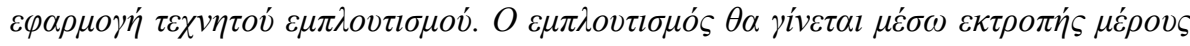

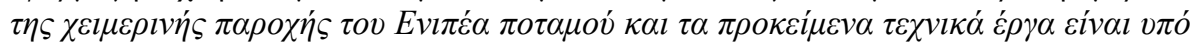

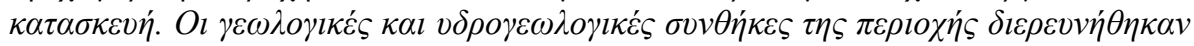

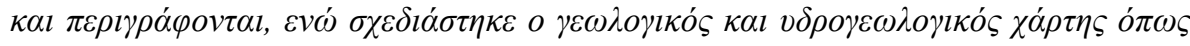

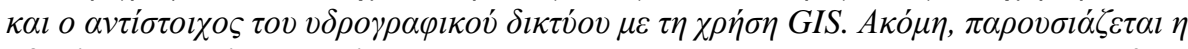

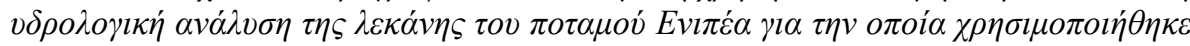

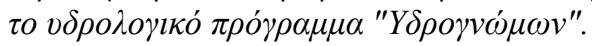




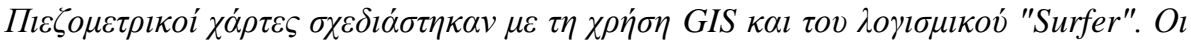

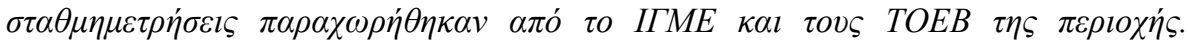

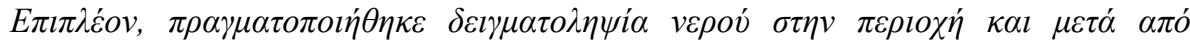

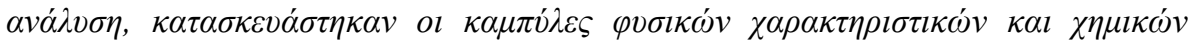

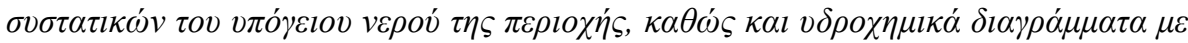

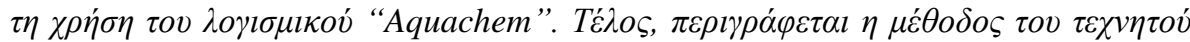

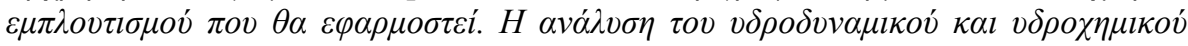

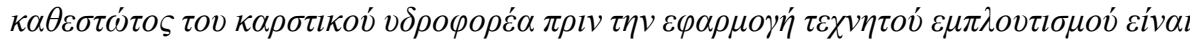

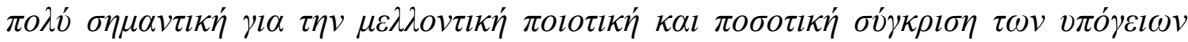

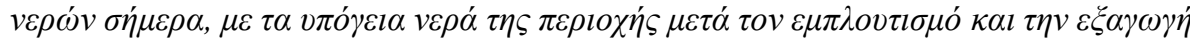
$\sigma v \mu \pi \varepsilon \rho \alpha \sigma \mu \alpha \dot{\tau} \tau \omega v$

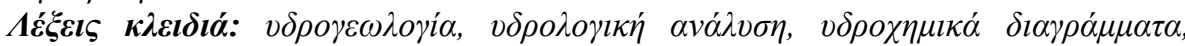

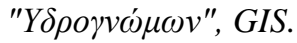

\section{Introduction}

The increase of cultivated areas in Orfana-Iperia site and generally in Thessaly during the past few years and the forecast for further future increase, resulted the increase of the water pumping amount. This fact causes the significant drawdown of the water table elevation, despite the enrichement of the aquifers in this region. It is representative of the situation, the ground water level in Hellinikon, as it is described in Table 2.

The application of artificial recharge of the aquifers was proposed in the area, considering that there are surface upsurges of the karstic aquifer of the region. The research about the artificial recharge in the karstic aquifer was studied by Mariolakos I. (July 2000), who elaborated a related research project in collaboration with the Kapodistriako University of Athens. The final study of the recharge, elaborated by technical companies in April of 2006, was based on Mariolakos' study.

\subsection{Geology-Hydrogeology of Orfana-Iperia}

The entire Thessaly plain consists a large tectonic submersion within the mountain of Pindos at the South-Southwest and Olympos, Ossa and Mavrovounio mountains at the Northeast. The OrfanaIperia site is part of the wider basin Thessaly, which is subdivided into two smaller basins; the one at the Eastern site (Larissa) and the other at the Western part of Thessaly. Also, it is important to mention that each one of the sub-basins consists of partial hydro-geological units, which locally show a merged hydraulic connection, while in other parts are completely independent (Mariolakos I., July 2000).

Noteworthy is the surface upsurge of the karstic aquifer of the region, in Fillion Mountain and in Chtouri hill. These two "karstic tanks" are surrounded by an aquifer consisting of microgranular materials. The karstic aquifer and the microgranular aquifer are connecting hydraulically.

Regarding the geology and hydro-geology of Orfana-Iperia site, the geological and hydro-geological maps of the area, along with the depiction of the hydro-graphic network were developed by means of GIS.

\section{Hydro-Meteorological Analysis, Hydrognomon Software}

The main source of recharge in the area comes from the precipitation, so the climatic characteristic $\mathrm{s}$ of the area were evaluated. The climate of flay Thessaly is characterized by a relative uniformity, as far as the geographical distribution of the mean monthly temperatures is concerned, although di ssimilarity is observed for precipitation across the area. In fact, the distribution of precipitation gen erally reveals an increase from the East to the West. Particularly, during the summer period the am ount of rainfall appears to be decreased in the area of Trikala than in the area of Karditsa. 


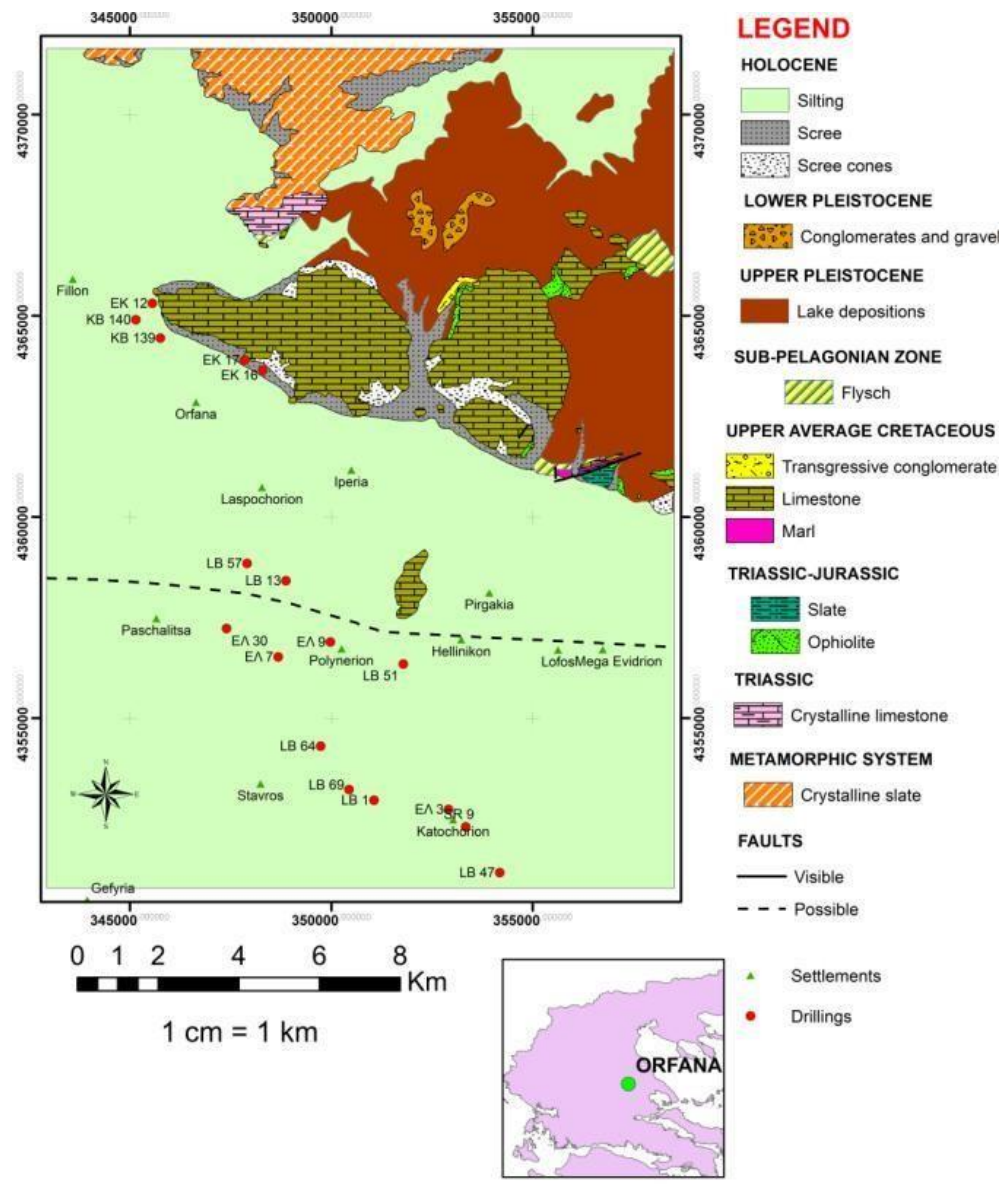

Figure 1 - Geological map of Orfana-Iperia site.

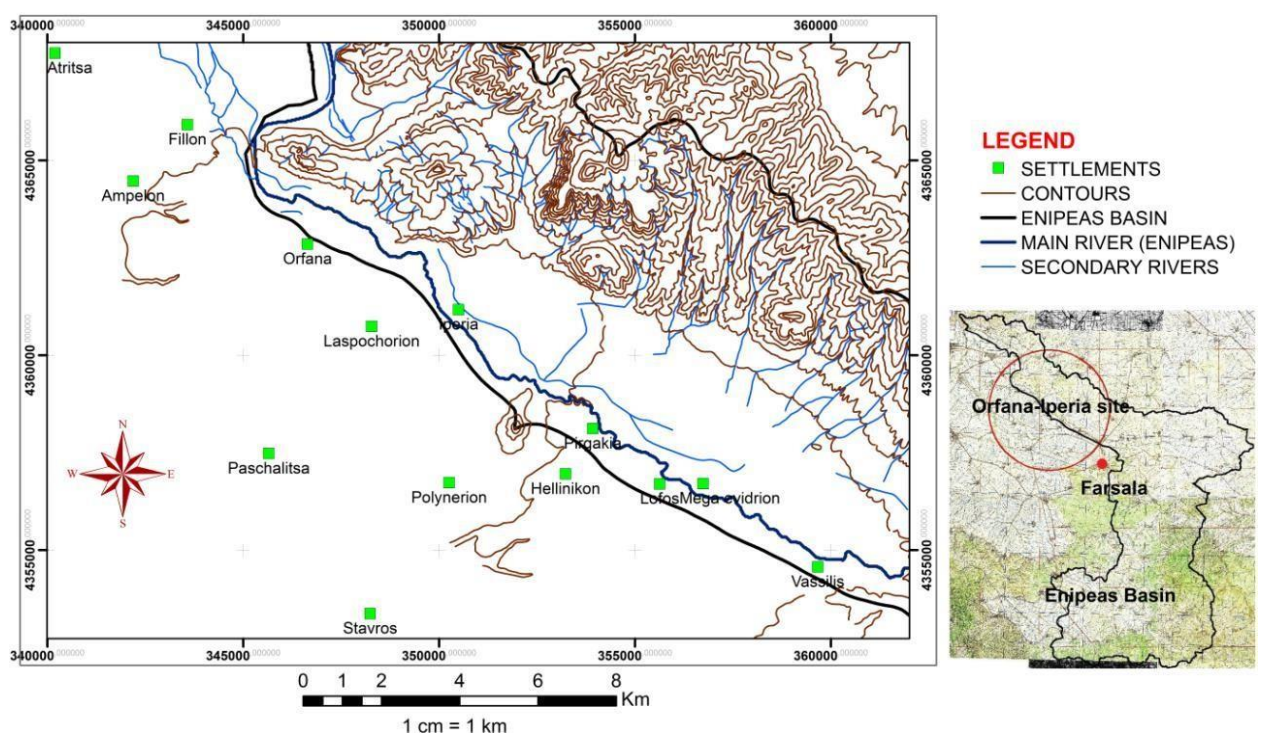

Figure 2 - Depiction of the hydro-graphic network of Orfana-Iperia site. 
The same distribution is valid for relative humidity. However, quite interesting is the fact that summer rainfalls are actually quite dense. Nevertheless, the former do occur mostly in the form of storms.

Firstly, the precipitation of the hydro-geological basin, which is traversed by through Enipeas River, was estimated. However, at this point it is important to add that prior to analysing the precipitation data of the observatory stations, the checking of the quality and completeness of the collected sample was significant too. For that reason, inspection of the homogeneity, completion and extension for 63 years (10/1950-9/2013) of the rainfall and temperature timeseries was recorded. This analysis was done using the hydraulic program "Hydrognomon".

Then, the potential evapotranspiration was estimated with the Blaney-Criddle method and the monthly runoff was calculated based on the rain-runoff model "Zygos". Infiltration was estimated too, based on the foregoing data. Finally, from the calculation of the water balance, it is estimated that a portion of $72.9 \%$ per year $\left(426.3 * 10^{6} \mathrm{~m}^{3}\right)$ of precipitations is evapotranspirated, while a portion of $16.8 \%$ per year $\left(98.4 * 10^{6} \mathrm{~m}^{3}\right)$ runoffs in the surface. The remaining portion of $10.3 \%$ per year $\left(59.5 * 10^{6} \mathrm{~m}^{3}\right)$ is attributed to the infiltration of rainfall in the aquifer.

According to Mariolakos' research, the average annual quantity of Enipeas River runoff that can be used for recharge in order not to disturb the normalcy of the river is about $16.7 * 10^{6} \mathrm{~m}^{3}$. For the same reason the water intake must not be done during the dry season of the year (May till September) in order not to disturb the operation of the river. According to the same study, $4.5^{*} 10^{6} \mathrm{~m}^{3}$ of the total amount of precipitation that infiltrates in the basin of the Enipeas River, infiltrates directly into the "karstic tank" of Fillion Mountain. Also, this karstic aquifer is enriched with an additional $19.1 * 10^{6}$ $\mathrm{m}^{3}$ of water, which infiltrates through the granular aquifer. The whole of the above quantities of water that will enrich the karstic aquifer are estimated in about $40.3 * 10^{6} \mathrm{~m}^{3}$.

The hydrological analysis is important because the resulting information in conjunction with the information that is derived from the piezometric analysis will help to draw conclusions about the recharge that will be applied.

Table 1 - Meteorological Station Data.

\begin{tabular}{|c|c|c|}
\hline Name & Basin & Altitude (m) \\
\hline Karditsa & Pinios River & 106.7 \\
\hline Anavra & Pinios River & 196.3 \\
\hline Loutropigi & Pinios River & 722.1 \\
\hline Skopia & Pinios River & 444.7 \\
\hline Zappeio & Pinios River & 172.3 \\
\hline
\end{tabular}

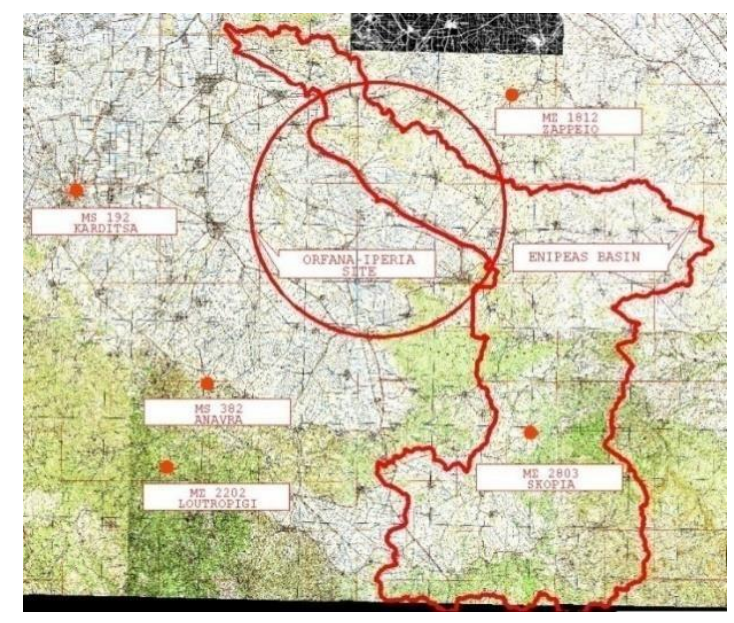

Figure 3 - Position of Meteorological Stations. 


\section{Piezometric Analysis}

For defining the piezometric condition of the area, piezometric maps for May and September of 2005, June and September of 2006 and April of 2007 were developed, using data from Geology and Mineral Investigations Institute's studies. This analysis was done using the GIS and the "Surfer" software. From the developement of these maps, useful results concerning the piezometry of the area were extracted. Also, results of Sideri (2008) piezometric analysis in the neighboring area of Stavros-Farsala were noticed and comparisons with the results of this study were made.

In general, the piezometric surface implies a decreasing trend, mainly due to the overpumping of the aquifer. This trend though was interrupted from a period of balance of the groundwater level, which was recorded in the period 1999 to 2006.

According to Mariolakos' research, the annual increase in the deficit of the karstic aquifer is about $2.1 * 10^{6} \mathrm{~m}^{3}$.

The piezometric maps were drawn by the "Surfer" software and the piezometric maps of Sideri's thesis (Athens, 2008) are also presented below. In these maps it is clear the status of the groundwater level in the territory.
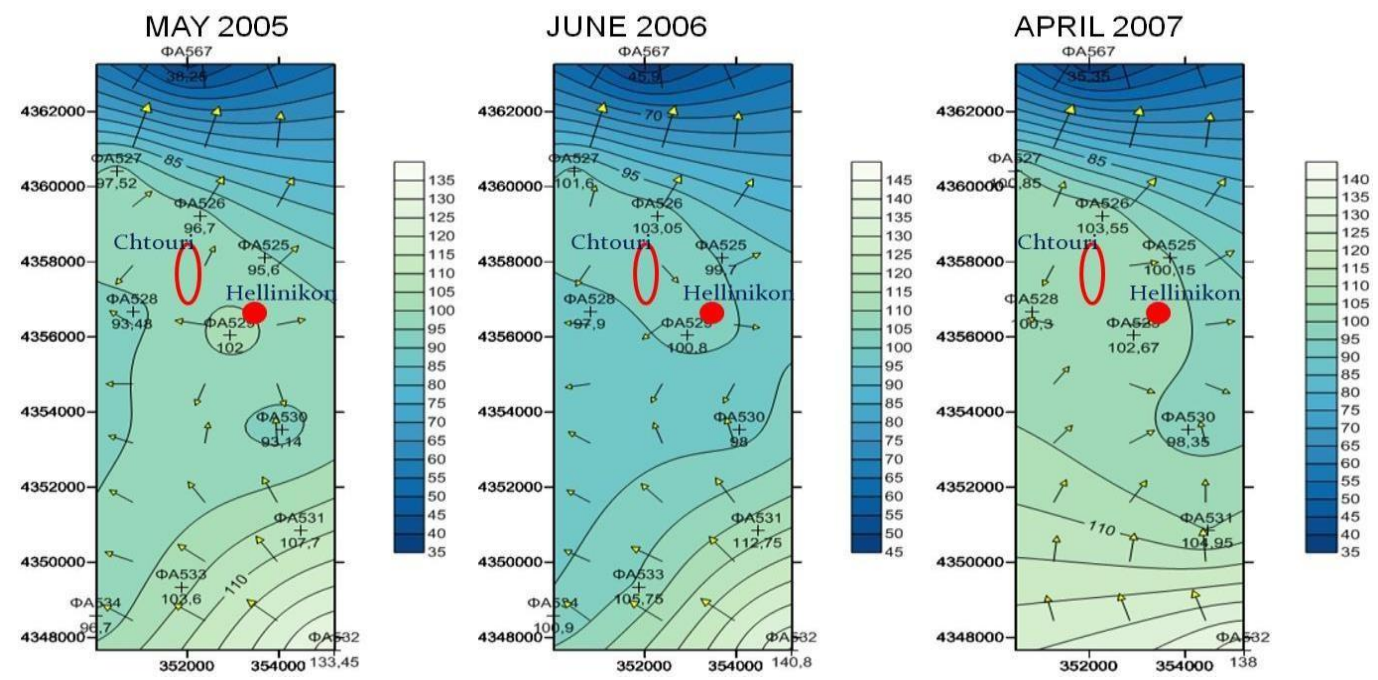

Figure 4 - Piezometry of Orfana-Iperia site (Level measurements provided by the Geology and Mineral Investigations Institute).

\section{Groundwater Quality Factors and Findings}

The described research was later complemented with the water sampling from seventeen (17) drillings in Orfana-Iperia site. The chemical analyses were performed in the relevant lab of the School of Mining and Metallurgical Engineering and in the Chemistry Laboratory of the Technological and Cultural Park of Lavrio of National Technical University of Athens (NTUA).

Following the chemical analyses, the hydro-chemical diagrams were drawn via Aquachem software (Figure 6-10). Observations of the main chemical compositions of groundwater were made and the suitability of the water for potable and irrigation use was examined.

The main results of the tests are presented in the Table 2. 


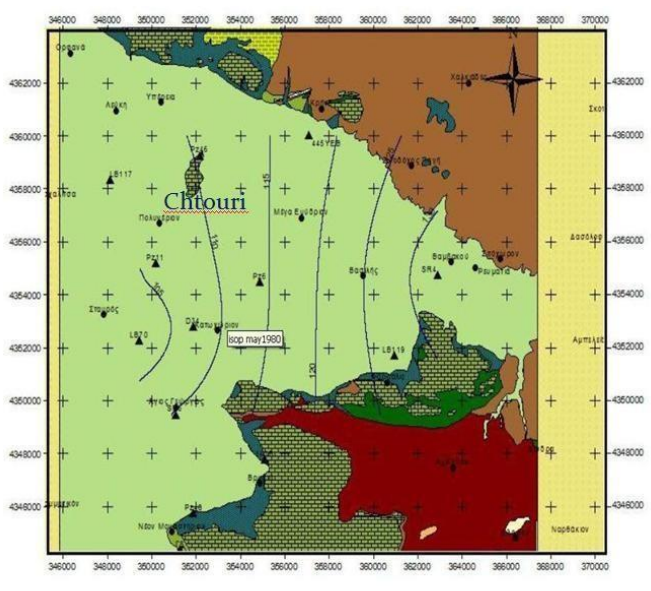

MAY1980

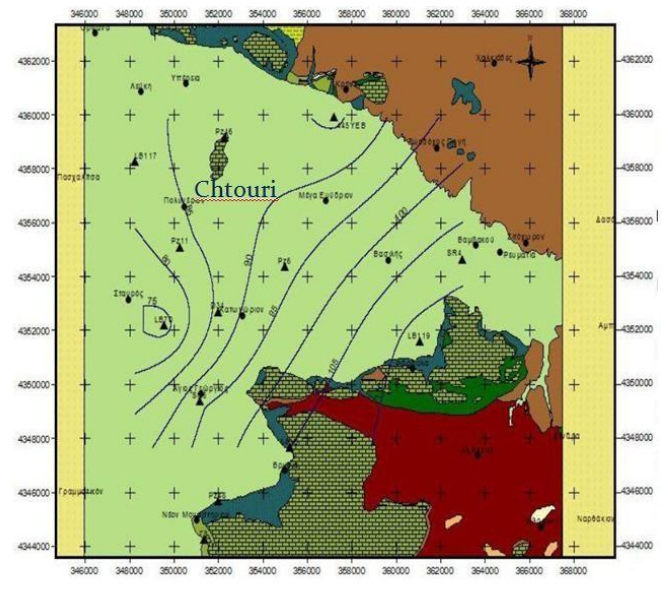

MAY2007

Figure 5 - Piezometric maps of Orfana-Iperia site (Sideri, 2008).

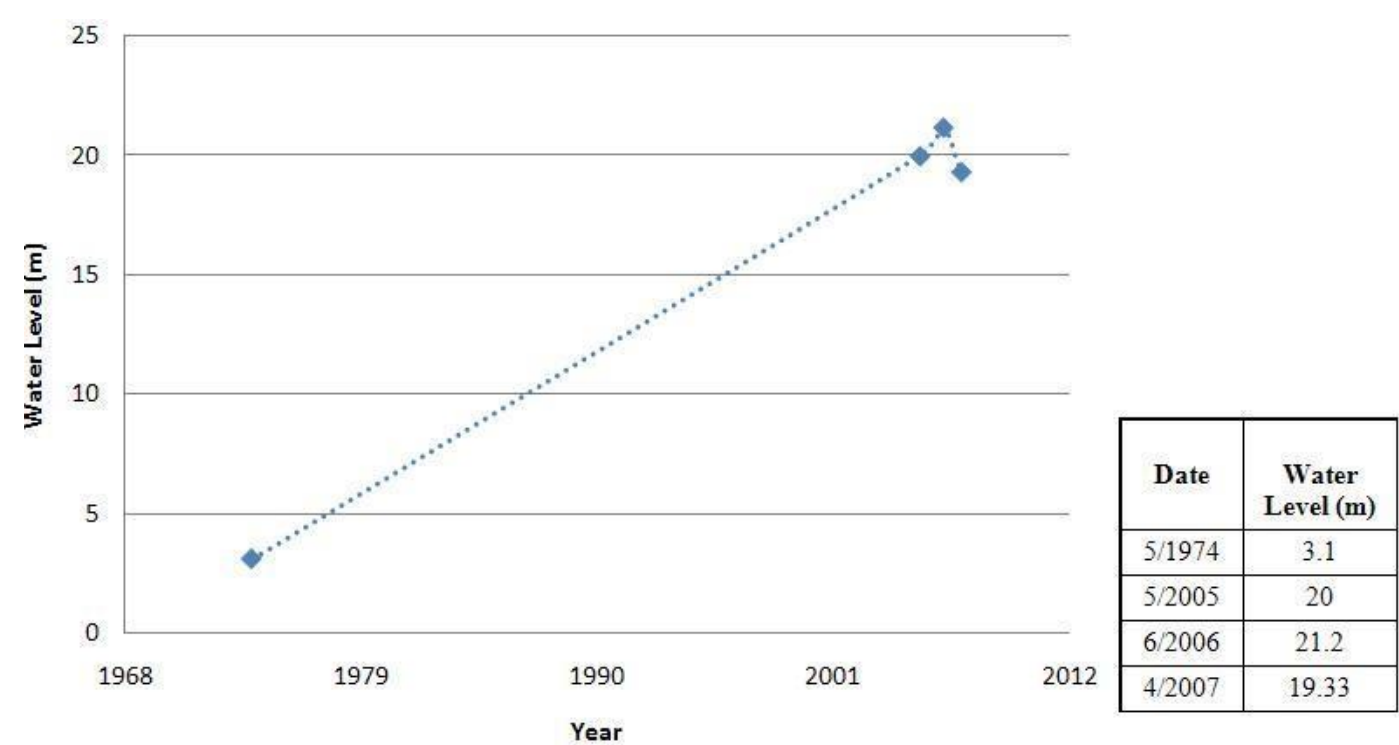

Figure 6 - Water Level in Hellinikon. 
Table 2 - Chemical analysis results in Orfana-Iperia site.

\begin{tabular}{|c|c|c|c|c|c|c|c|c|c|c|c|c|}
\hline Site & $\begin{array}{c}\text { Drilling } \\
\text { Code }\end{array}$ & pH & $\mathbf{T}\left({ }^{\circ} \mathrm{C}\right)$ & $\begin{array}{c}\mathrm{EC} \\
(\mu \mathrm{S} / \mathrm{cm})\end{array}$ & $\begin{array}{c}\mathrm{Na}+ \\
(\mathrm{mg} / \mathrm{l})\end{array}$ & $\begin{array}{c}\mathrm{K}+ \\
(\mathrm{mg} / \mathrm{l})\end{array}$ & $\begin{array}{l}\mathrm{Ca}++ \\
(\mathrm{mg} / \mathrm{l})\end{array}$ & $\begin{array}{l}\mathrm{Mg}++ \\
(\mathrm{mg} / \mathrm{l})\end{array}$ & $\begin{array}{c}\mathrm{Cl}- \\
(\mathrm{mg} / \mathrm{l})\end{array}$ & $\begin{array}{l}\mathrm{HCO3} \\
(\mathrm{mg} / \mathrm{l})\end{array}$ & $-\begin{array}{l}\text { NO3- } \\
(\mathrm{mg} / \mathrm{l})\end{array}$ & $\begin{array}{l}\text { SO4- } \\
(\mathrm{mg} / \mathrm{l})\end{array}$ \\
\hline \multirow{6}{*}{ Polyneri } & LB13 & 6.754 & 13.3 & 880 & 88.2 & 1.9 & 78 & 41 & 81 & 427 & 19.7 & 27 \\
\hline & LB51 & 6.648 & 11.0 & 662 & 28.5 & 0.6 & 82 & 37 & 18.1 & 305 & 28.8 & 27 \\
\hline & LB57 & 6.813 & 12.8 & 820 & 130.2 & 1 & 45 & 24 & 36.1 & 305 & 10 & 37 \\
\hline & E $\Lambda 7$ & 6.885 & 13.5 & 582 & 72 & 0.6 & 47 & 28 & 16.7 & 366 & 9.7 & 9 \\
\hline & E\9 & 6.716 & 12.5 & 651 & 38.9 & 0.4 & 65 & 22 & 38.1 & 366 & 1 & 20 \\
\hline & $\mathrm{E} \Lambda 30$ & 6.779 & 13.1 & 603 & 90.4 & 0.7 & 42 & 18 & 28.2 & 305 & 6.3 & 15 \\
\hline \multirow{6}{*}{$\begin{array}{l}\text { Stavros - } \\
\text { Katochori }\end{array}$} & LB1 & 6.688 & 12.6 & 704 & 51.2 & 0.5 & 111 & 75 & 25.1 & 549 & 4.1 & 25 \\
\hline & LB47 & 6.684 & 12.9 & 616 & 33.8 & 0.7 & 92 & 45 & 7.7 & 305 & 39.2 & 21 \\
\hline & LB64 & 6.797 & 14.0 & 577 & 44.9 & 0.5 & 82 & 32 & 19.4 & 366 & 7.4 & 11 \\
\hline & LB69 & 6.903 & 14.4 & 700 & 46.9 & 0.4 & 98 & 61 & 37.3 & 305 & 4.4 & 23 \\
\hline & E\3 & 6.903 & 14.4 & 703 & 40.6 & 0.6 & 82 & 41 & 34 & 305 & 26.6 & 21 \\
\hline & SR9 & 6.644 & 13.0 & 633 & 28.1 & 0.6 & 101 & 53 & 21 & 427 & 20.4 & 20 \\
\hline \multirow{5}{*}{$\begin{array}{l}\text { Fillio } \\
\text { Oros }\end{array}$} & \begin{tabular}{|l|} 
KB139 \\
\end{tabular} & 6.863 & 14.3 & 657 & 40.1 & 1.1 & 94 & 49 & 16 & 427 & 18.5 & 32 \\
\hline & KB140 & 6.685 & 12.7 & 619 & 35.1 & 0.9 & 78 & 48 & 17 & 305 & 20.4 & 22 \\
\hline & EK12 & 6.706 & 13.5 & 601 & 30.2 & 1.4 & 88 & 45 & 14 & 366 & 26 & 20 \\
\hline & EK16 & 6.722 & 14.0 & 604 & 28.9 & 1.3 & 71 & 32 & 15 & 305 & 19.6 & 21 \\
\hline & EK17 & 6.846 & 14.5 & 609 & 31.2 & 1.4 & 71 & 24 & 9 & 366 & 23.5 & 20 \\
\hline
\end{tabular}

The results of the above chemical analyses revealed high levels of Magnesium $(\mathrm{Mg})$ and Nitrates for the groundwater of the study area. High levels of Magnesium $(\mathrm{Mg})$ were detected due to the soil texture of the alluvial deposits and the presence of ultramafic rocks. In addition, the increased concentrations of nitrates are a direct consequence of the intensive usage of fertilizers and pesticides in the area for agriculture purposes. The hydrochemical diagrams are presented below:

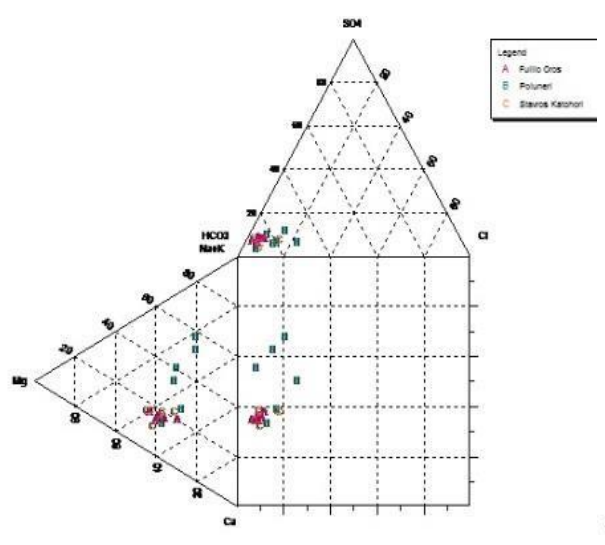

Figure 7 - Durov diagram.

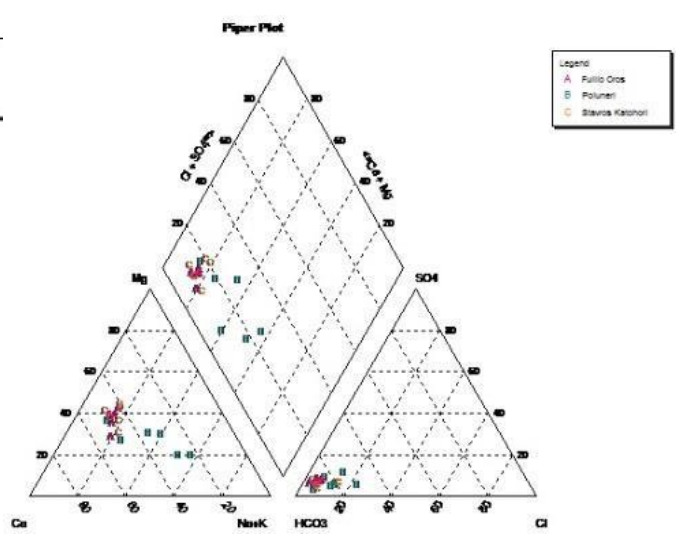

Figure 8 - nPiper diagram. 


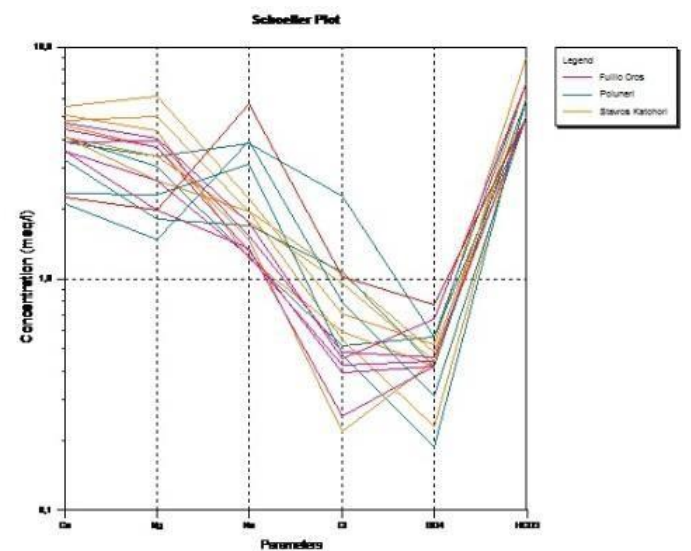

Figure 9 - Schoeller diagram.

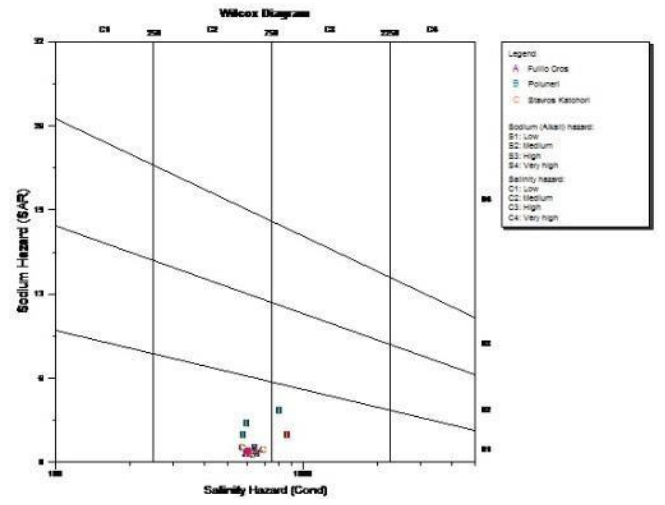

Figure 10 - Wilcox diagram.

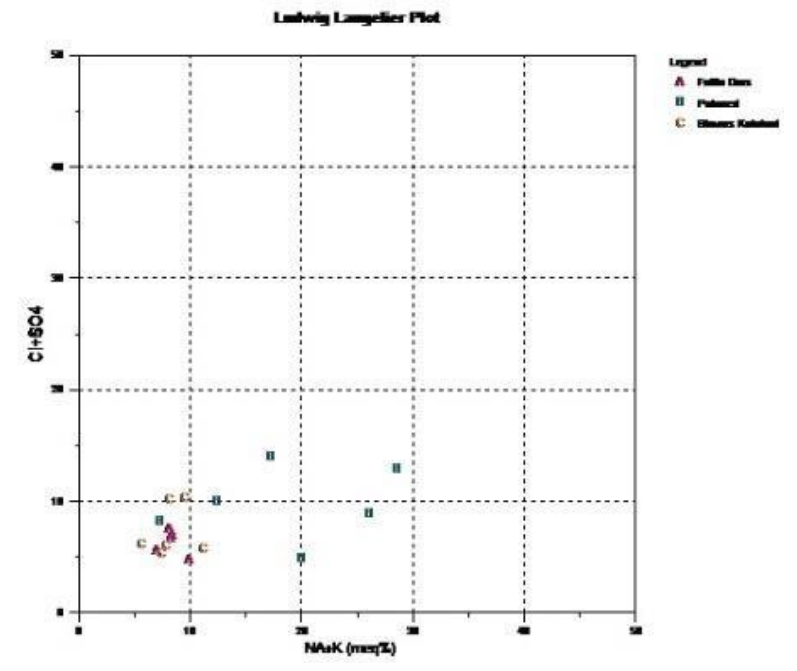

Figure 11 - Ludwig Langelier diagram.

\section{Artificial Ground Water Recharge, Recharge Site Fillion Mountain}

Artificial ground water recharge at Orfana-Iperia will be achieved by the divertion of a portion of the flow of Enipeas River in the Karstic aquifer of Fillio Mountain. A diversion dam is already built on Enipeas River and the water will be conveyed through a ditch to the recharge site. There, ground water recharge will be made through a tunnel with recharge holes. The flow that has been calculated for the design of the water transportation constructions for artificial enrichment is $Q=5 \mathrm{~m}^{3} / \mathrm{sec}$. However, during the construction of the tunnel, it has been confirmed that there has been excessive use of concrete for the construction of the holes, which obviously will cause the reduction of the desired infiltration. This is something that should be taken into consideration in order not to affect the profitability of the project. 

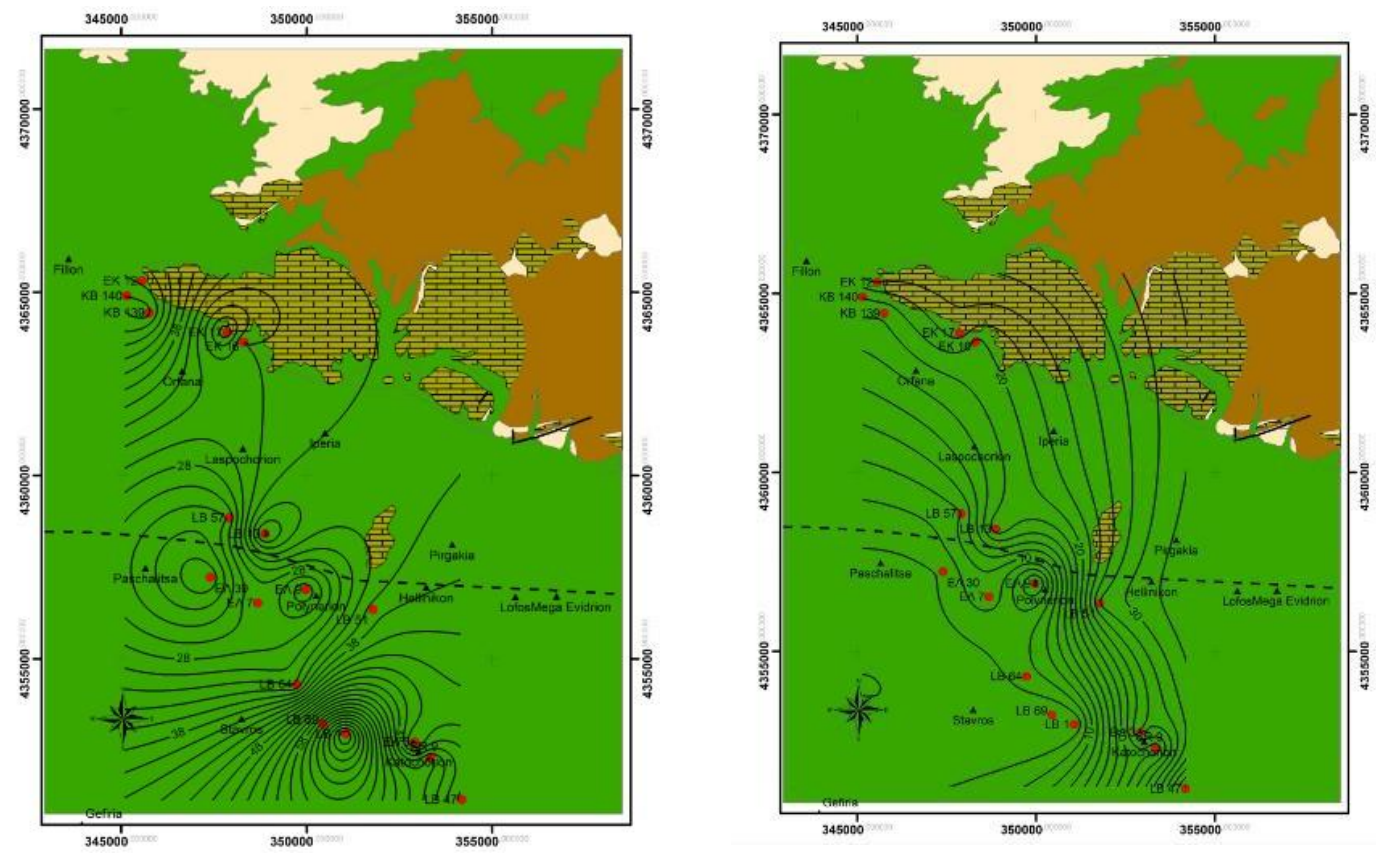

Figure 12 - Hydrochemical map of $\mathrm{Mg}$ and $\mathrm{NO}_{3}$ destribution in Orfana - Iperia.

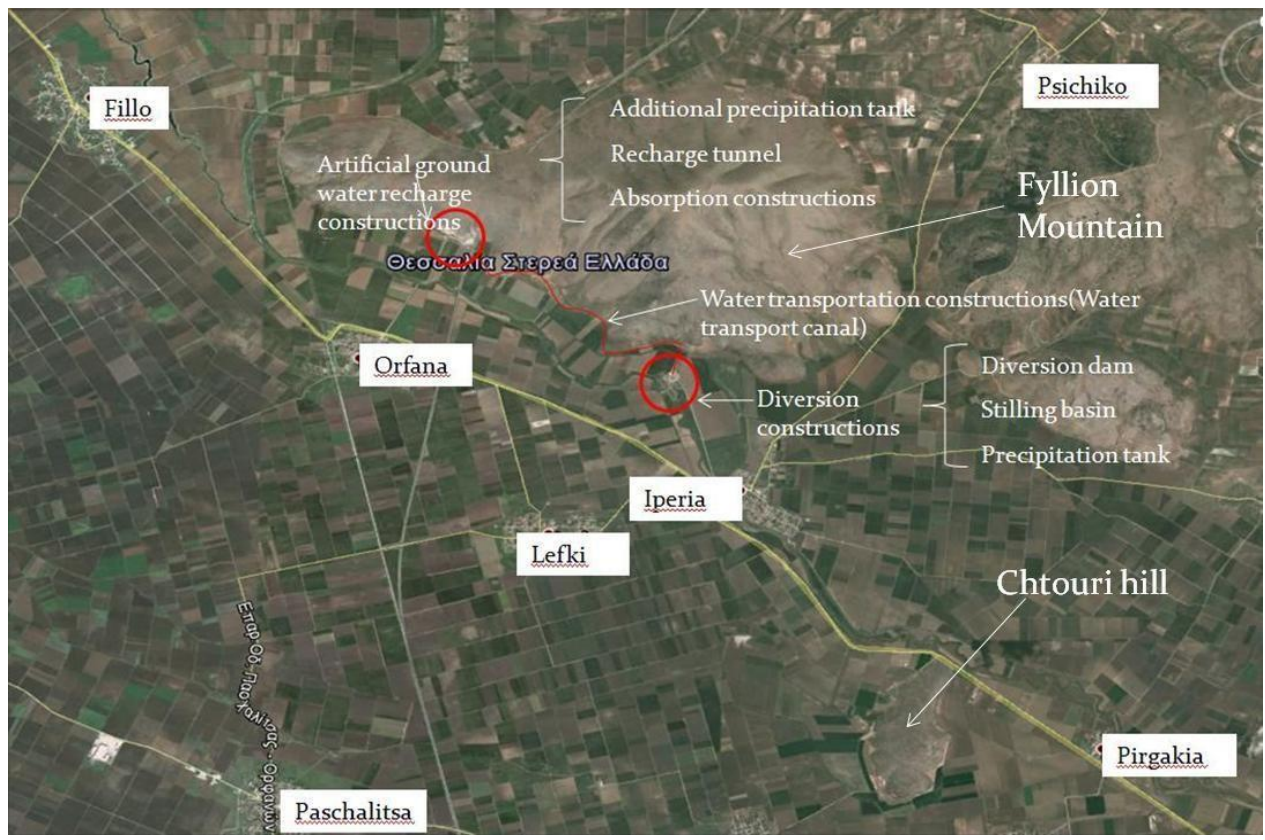

Figure 13 - Future Artificial ground water recharge constructions.

\section{Results and Conclusion}

Initially, it was argued that the largest section of the Thessaly aquifer is under a sever overexploitation regime as there is constant and systematic depression of water levels year after year. Nevertheless, it was found that the volume of overexploitation varies across the local area. The same 
is true as for the timing that the sudden decrease in the groundwater level begun, without any action taken for its substitution.

The study led to the following conclusions:

- The area that is cultured exceeds 100.000 acres and is irrigated with boreholes.

- The depletion of groundwater is a major problem and the application of artificial ground water recharge is vital for the substitution of the aquifers.

- The artificial recharge will be achieved using water from Enipeas' river runoff by diversion. The maximum amount of Enipeas' river water that will be diverted is $16.700 .000 \mathrm{~m}^{3} / \mathrm{y}$. The water intake must be done during the wet season in order not to disturb the operation of the river.

- The amount of water that is going to enrich the karstic aquifer is sufficient both to compensate the annual increase in the deficit of the karstic aquifer and for the gradual equalization of the total deficit that has been created due to overexploitation for years.

- As shown by the chemical analysis, the quality of water of the region is good and suitable for irrigation.

- The artificial ground water recharge constructions must be done according to the specifications of the final study of the project in order to avoid the reduction of the infiltration that is needed. That is important for the profitability of the project.

\section{References}

Hydrodynamic EU, Technical Engineering Company TEC SA, Kostopoulos. S., Myrisiotis, E. and Kiriakakis, Ch., April 2006. Study of artificial underground water recharge projects of Orfana-Iperia karstic system, Final Study, Athens.

Kallergis, G., Morfis, A., Papaspiropoulos, Ch. and Christodoulou, Th., 1973. Hydrogeological research of West Thessaly basin, Institute of Geological and Mineral Exploration, Athens.

Kozanis, S., Christoforidis, A. and Efstratiadis, A., 2005. Description of the management and data processing system "Hydrognomon", Integrated Management of Hydrosystems in Conjunction with an Advanced Information System (ODYSSEUS), Contractor NAMA, Issue 2, Department of Water Resources, Hydraulic and Maritime Engineering, National Technical University of Athens, Athens.

Mamassis, N., 2007. Notes on Advanced Hydrology, Hydrological models and applications, Laboratory of Hydrology and Water Resources, IPPS Water Resources Science and Technology, National Technical University of Athens, Athens.

Mariolakos, I., Lekkas, S., Alexopoulos, A., Papadopoulos, T., Fountoulis, I., Shneider, I., Alexopoulos, I., Mpantekas, I., Spiridonas, E., Mariolakos, D. and Andreadakis, E., 2000. Hydrogeological Study of Artificial Groundwater Recharge of Orfana-Iperia Karstic Aquifer, Research Study of Geological University of Athens, Athens.

Papagiannis, N., 2015. Karstic aquifer of Orfana - Iperia of Thessaly Hydrodynamic and Hydrochemical status before the artificial ground water recharge, National Technical University of Athens, Athens.

Sideri, D., 2008. The research and analysis of the hydro-geological regime and the study of the land subsidence phenomena which occur as a direct result of groundwater overpumping in Stavros-Farsala of West Thessaly, National Technical University of Athens, Athens.

Vafiadis, P., 1995. Artificial ground water recharge of the aquifers, Thessaloniki. 